\title{
A Stranger in the Epididymis: Ectopic Spleen
}

\author{
Epididimde Bir Yabancl: Ektopik Dalak
}

\author{
(1) Yelda Dere1, (1) Illker Akarken², (1) Özgür İlhan Çelik1', (1) Hayrettin Şahin² \\ ${ }^{1}$ Muğla Sıtkı Koçman University Faculty of Medicine, Department of Pathology, Muğla, Turkiye \\ 2Muğla Sıtkı Koçman University Faculty of Medicine, Department of Urology, Muğla, Turkiye
}

\begin{abstract}
Splenogonadal fusion, which can be clinically confused with testicular neoplasms as they present with testicular swelling, is a rare abnormality in young adults. Intraoperative frozen section analysis can be helpful in diagnosing such cases and preventing unnecessary orchiectomies. We report a case in which frozen section analysis was done and testis-sparing surgery could be performed.
\end{abstract}

Keywords: Splenogonadal fusion, Ectopic spleen, Testis

\section{Öz}

Splenogonadal birleşme genç erişkinlerin testiste şişlik ile bulgu veren ve testis tümörleri ile klinik olarak karışabilen nadir bir anomalisidir. Operasyon esnasında patolojik olarak frozen kesit ile inceleme bu tip olguların gereksiz orşiektomiden korunması açısından yardımcı olabilir. Biz de operasyon esnasında frozen kesit ile incelenen ve bu sayede testis koruyucu cerrahi uygulanabilen bir olgumuzu sunduk.

Anahtar Kelimeler: Splenogonadal birleşme, Ektopik dalak, Testis

\section{Introduction}

Splenogonadal fusion (SGF), which is one of the rarest congenital abnormalities in the genital tract, is defined as the ectopic localization of the splenic tissue in/between the mesonephric tissues such as gonadal or perigonadal tissues. SGF is generally seen in men (1) as a scrotal mass or an incidental finding during other surgical procedures, such as hernia repair, but the real incidence remains a mystery (2).

SGF is classified into continuous and discontinuous types. In continuous type, the normal spleen is attached to the gonads, however, in the discontinuous type, ectopic splenic tissue is attached to the gonads showing no connection to the normal spleen.

Herein, we report a case of discontinuous type SGF presenting as a paratesticular mass in an 19-year-old patient.

\section{Case Presentation}

A 19-year-old patient with a history of crypthorchidism in the right testis presented with a palpable mass in the left scrotum.
The patient stated that this mass was there since childhood. Ultrasonography showed a mass of 29x25 $\mathrm{mm}$ in the upper part of the left scrotum. Magnetic resonance imaging demonstrated an extra testicular, well defined solid mass measuring $25 \times 28 \times 45$ $\mathrm{mm}$ in the upper part of the left scrotum.

Due to the presence of the medical history of cryptorchidism, testis-sparing surgery with intraperative frozen section analysis was planned. A small, well defined and semi solid mass was excised from the proximal part of the epididymis and sent to our pathology laboratory for frozen section analysis (Figures $1 \mathrm{a}, \mathrm{b})$. In macroscopic examination, the mass was measured as $4 \times 2.5 \times 2 \mathrm{~cm}$, had a ruptured capsule and a brown cut surface. In the microscopic frozen section of the mass, we observed slit-like spaces with lymphoid cell aggregates dispersed in the parenchyma and reported as benign and the operation ended with no orchiopexy (Figures 2 and 3). In the paraffin-embedded (permanent) sections of the mass, the slit-like spaces were thought to be the glandular parts of an adenomatoid tumor or vascular structures and they stained negative for calretinin and CK7 and positive for CD34. When dispersed lymphoid aggregates

Correspondence: Yelda Dere MD, Muğla Sıtkı Koçman University Faculty of Medicine, Department of Pathology, Muğla, Turkiye E-mail: yeldamorgul@gmail.com ORCID-ID: orcid.org/0000-0003-0238-2236

Received: 01.11.2017 Accepted: 10.12.2017

Cite this article as: Dere Y, Akarken İ, Çelik Öi, Şahin H. A Stranger in the Epididymis: Ectopic Spleen. J Urol Surg 2018;5(4):221-223.

๑ Copyright 2018 by the Association of Urological Surgery / Journal of Urological Surgery published by Galenos Publishing House. 
were taken into account, the vascular structures were decided to be the sinusoids and the lymphoid aggregates were thought to be the white pulp of an ectopic spleen. Considering these findings, the final diagnosis of ectopic splenic tissue was established. The patient got no additional medication and was well after 3 months of follow-up.

Written informed consent was taken from the patient before the operation.

\section{Discussion}

SGF is a rare entity presenting as a swelling that can be seen in both females and males, however, more common in men and generally in the left testis (3).

Although many other congenital abnormalities, such as cardiac malformations, micrognathia, and spina bifida, have been reported in the literature, the most common abnormality is cryptorchidism. Duncan and Barraza (4) reported a case of SGF

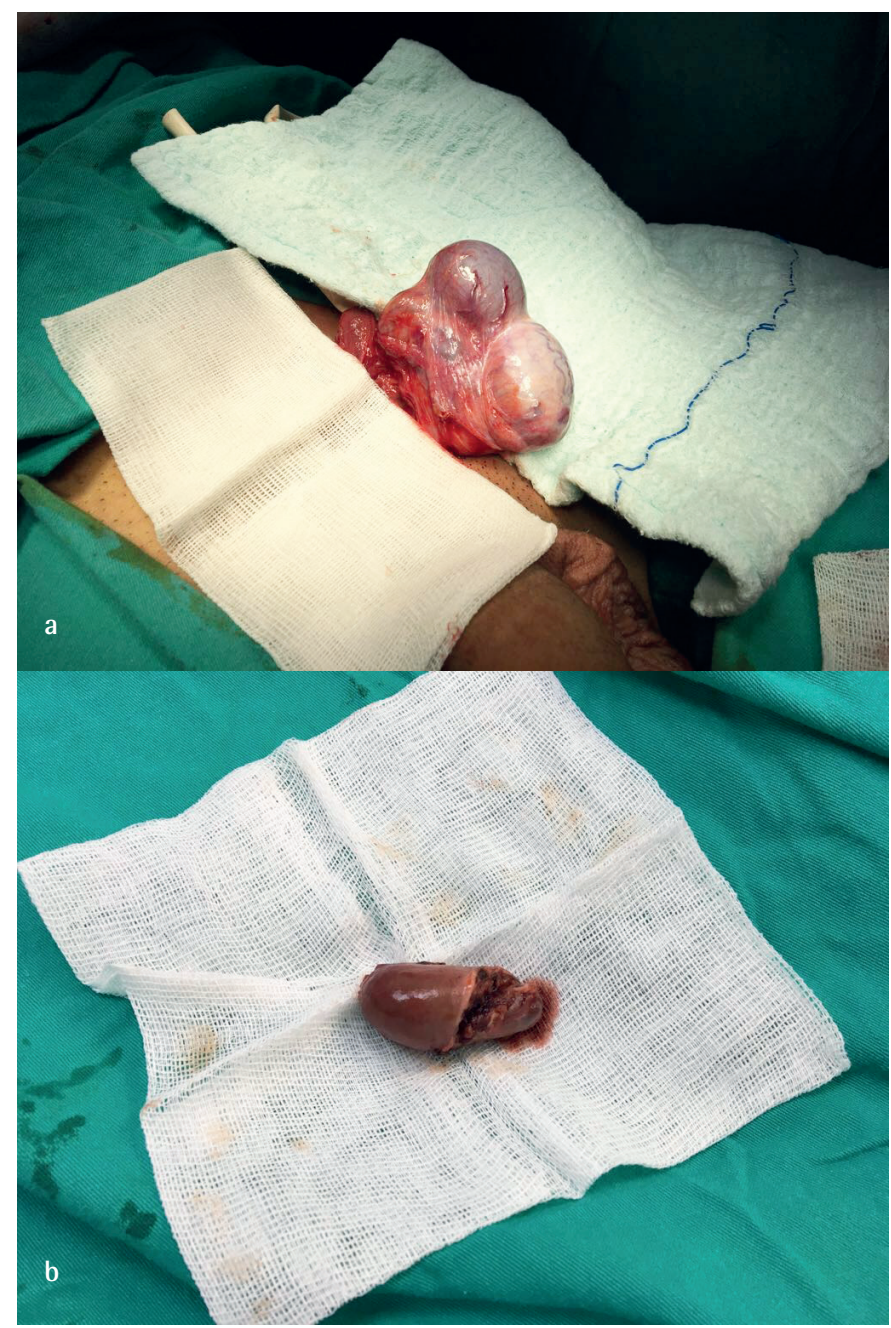

Figure 1. Macroscopic appearance of the mass in the operation (a) and after the excision (b) associated with bilateral cryptorchidism and hypospadias.

Testicular swelling is the most common symptom, however, incidental diagnoses have also been reported in addition to three cases of SGF associated with testicular tumors $(3,5)$.

As many imaging studies can be performed for diagnosing these cases before surgery, 37\% of cases need orchiectomy because of unpredictable diagnosis of testicular neoplasms (3). Intraoperatively, frozen section analysis can also be helpful in avoiding unnecessary orchiectomy (6).

In addition, in cases where the lesion is located around the testis and testis-sparing surgery is planned, frozen section analysis is very helpful as seen in our case.

In conclusion, SGF should be kept in mind especially in young adults with long-term testicular swelling and frozen section analysis can be used to prevent unnecessary orchiectomies.

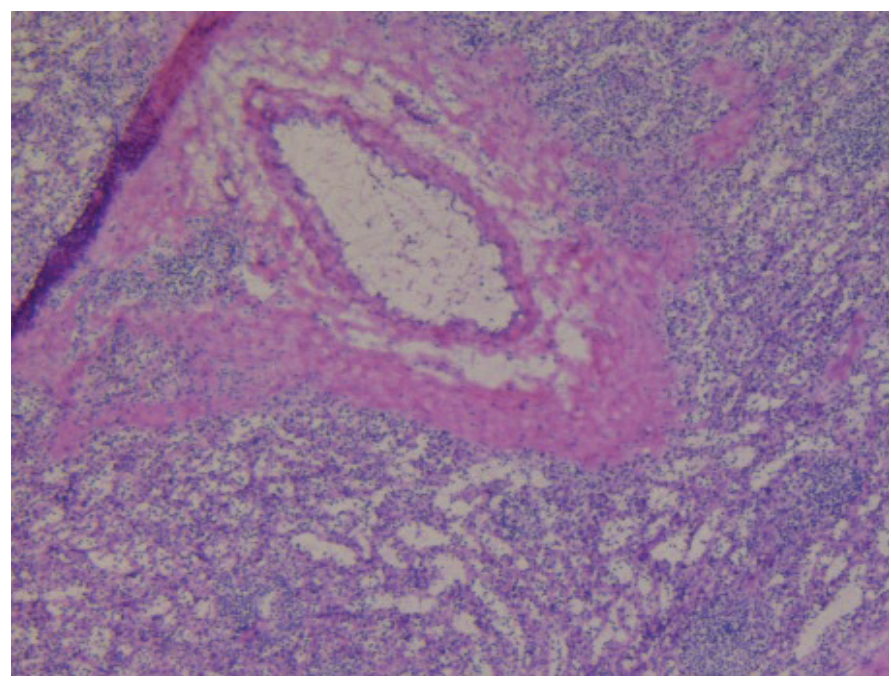

Figure 2. Frozen section of the mass showing slit like spaces and lymphoid aggregates (hematoxylin and eosin, 40x)

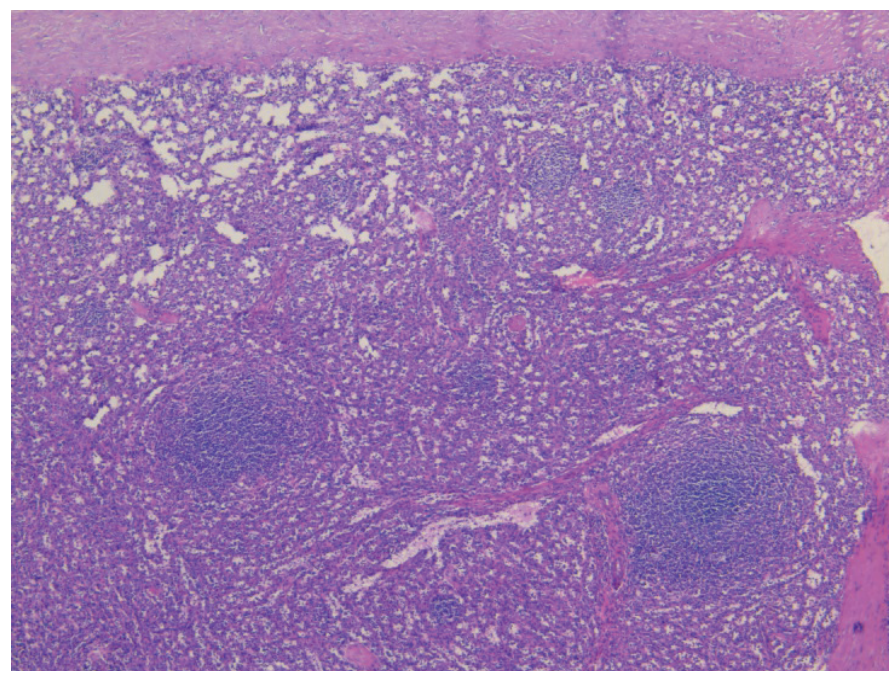

Figure 3. Permanent parafine sections revealing the sinuzoids and the white pulp (hematoxylin and eosin, 40x) 


\section{Acknowledgments}

Special thanks to Prof. Dr. Kutsal Yörükoğlu for his contribution in this case.

\section{Ethics}

Informed Consent: It was taken from the patient before the operation.

Peer-review: Externally peer-reviewed.

\section{Authorship Contributions}

Surgical and Medical Practices: Y.D., I.A., Ö.I.Ç., Concept: Y.D., Ö.I.Ç., Design: Y.D., I.A., H.Ş., Data Collection or Processing: I.A., Analysis or Interpretation: Y.D., I.A., Literature Search: Ö.I.Ç., H.Ş., Writing: Y.D., I.A.

Conflict of Interest: No conflict of interest was declared by the authors.
Financial Disclosure: The authors declared that this study received no financial support.

\section{References}

1. Alvarez Maestro M, López-Tello J, Domínguez Franjo P, Ríos González $E$, Martinez-Piñeiro L. Splenogonadal fusion. Report of a case and review of the literature. Actas Urol Esp 2010;34:293-295.

2. Chiaramonte C, Siracusa F, Li Voti G. Splenogonadal Fusion: A Genetic Disorder?-Report of a Case and Review of the Literature. Urol Case Rep 2014;2:67-69.

3. Shen XC, Du CJ, Chen JM. Case report: Splenogonadal fusion. Zhejiang Da Xue Xue Bao Yi Xue Ban 2007;36:1.

4. Duncan WL Jr, Barraza MA. Splenogonadal fusion: A case report and review of literature. J Pediatr Surg 2005;40:5-7.

5. Bekar E, Yalta T, Yarıc H, Dogdas A, Tuncer Y. Ectopic Splenic Tissue in the Testis: A Case Report. African Journal of Urology 2009;15:180-182.

6. Trias Puig-Sureda I, Orsola los de Santos A, Raventós Busquets CX, Español Quintilla I, Bucar Terrades S. [Splenogonadal fusion. Report of a case] Actas Urol Esp 2007;31:559-561. 